
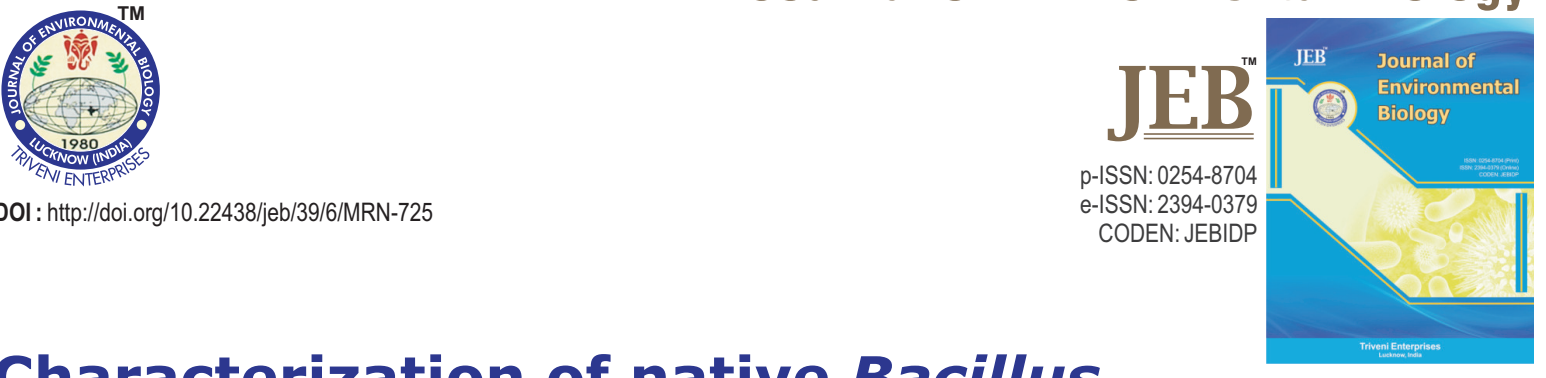

\title{
Characterization of native Bacillus thuringiensis strains for cytotoxicity against human cancer cell lines
}

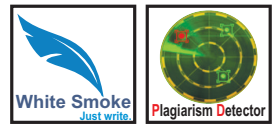

Authors Info

M.K. Oktay, B. Şahin and H. Güneş*

Department of Biology, Faculty of Science, Muğla Sıtkı Koçman University, 48000, Muğla, Turkey

${ }^{*}$ Corresponding Author Email : haticegunes@mu.edu.tr

\section{Key words}

Bacillus thuringiensis

Cancer cell lines

Cyt genes

Cytotoxicity

Parasporin

Publication Info

Paper received : 14.08 .2017

Revised received : 20.12.2017

Accepted: 05.02.2018

\section{Abstract}

Aim : The aim of this study was to characterize fourteen $B$. thuringiensis strains for cyt and parasporin gene contents as well as cytotoxicity of parasporal proteins against different cancer cell lines.

Methodology : PCR was applied for screening of cyt $1 /$ cyt 2 and six different parasporin genes. In addition, cyt negative (non-cyt) nine Bt strains were tested for hemolytic activity. Non-cyt and non-hemolytic parasporal proteins from nine Bt strains were alkali solubilized and activated by proteinase- $\mathrm{K}$ for in vitro cytotoxic activities.

Results : Five Bt strains carried cyt gene whereas only one strain Bt-Ba14 harbored parasporin 2 gene and showed $37 \mathrm{kDa}$ protein on SDS-PAGE. Non-cyt 9 Bt strains were confirmed to be non-hemolytic. MTT assay indicated that activated parasporal proteins $\left(10 \mu \mathrm{g} \mathrm{m}^{-1}\right)$ displayed selective cytotoxicity against HeLa, PC-3 and A549 cancer cell lines compared to a normal cell line BEAS-2B. Parasporal protein from Bt-Ba14 exhibited the highest cytotoxicity against all three cancer cells, however, not to normal cell line and caused cytocidal activity similar to that observed with parasporins.

Interpretation : The study reported that non-cyt and non-hemolytic Bt strains from Turkey have parasporal proteins with cytotoxic activities against cancer cells.

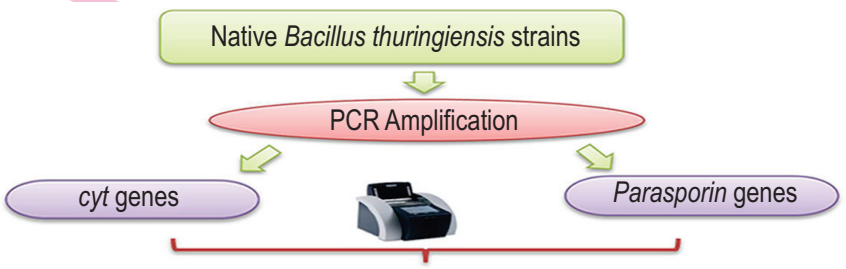

Selection of Non- cyt \& Non-Hemolytic and parasporin positive strains

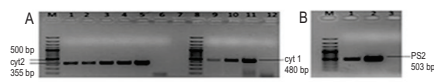

5
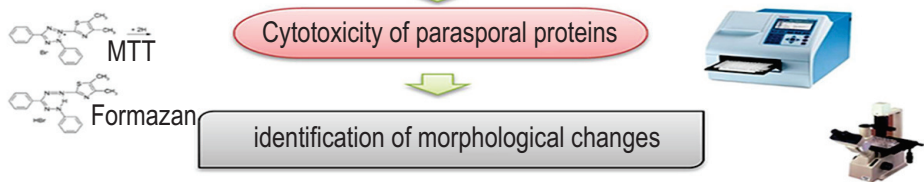

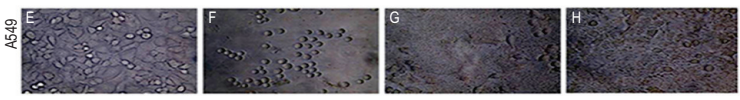




\section{Introduction}

Bacillus thuringiensis is a Gram positive, entomopathogenic and spore forming bacterium that produce parasporal inclusions during sporulation (Roh et al., 2007; Höfte and Whiteley, 1989). The parasporal crystalline proteins are made of delta-endotoxins and divided into two classes, Cry and Cyt proteins (Guerchicoff et al., 2001). The Cry protein has strong larvicidal activity specific for Lepidoptera, Coleoptera and Diptera (Schnepf et al., 1998), whereas Cyt protein has a wide range of cytolytic and hemolytic activities aganist different invertebrate and vertebrate cells (Crickmore etal., 1998; Palma etal., 2014).

Cry proteins exhibit their effects in the midgut epithelial cells of susceptible insect after certain processes including solubilization of the inclusions under alkaline conditions, proteolytic cleavage of protoxin by midgut proteases, binding to specific receptors located on the epithelial cell surface, and causing the pore formation that leads to cell lysis (Schnepf et al., 1998). Toxicity of Cyt toxin is not sufficient by itself; however, its insecticidal activity is mediated by synergistic interaction with the Cry proteins (Salehi et al., 2008; Soberon et al., 2012).

During last decades, more than 700 cry genes coding for Cry proteins have been determined (Palma, 2014). Even though many Cry proteins have insecticidal activity, some of them have toxicity against bacteria, nematodes, parasites and human cancer cells. In fact, non-insecticidal $B$. thuringiensis strains are more widely distributed than insecticidal strains in natural environments (Ohba, 2000; Mizuki et al., 1999). The biological role of these strains were unknown until Mizuki et al. (1999) had identified their function. They reported a unique cytocidal activity from non-insecticidal and non-hemolytic $B$. thuringiensis strains aganist human cancer cells. Bioactive molecule from these $B$. thuringiensis strains is called parasporin (Mizuki et al., 2000). So far, parasporins have been divided into six main classes starting from parasporin 1 (PS1) to PS6, and more than 18 subclasses have been added to the list (Wong et al., 2010; Okassov, 2015). The parasporal proteins of non-cytolitic (non-cyt) and noninsecticidal $B$. thuringiensis strains are highly toxic to human cancer cell lines in vitro because of their mammalian cell recognition and killing activity (Kim et al., 2000). Studies in the literature provides an evidence that parasporin activities were observed among the naturally occuring $B$. thuringiensis strains in different countries (Okassov, 2015). Therefore, in this present study, B. thuringiensis strains from Bt collection of $\mathrm{H}$. Gunes Molecular Biology Laboratory were characterized based on cyt and parasporin gene contents as well as in vitro cytotoxicity against human cancer cell lines.

\section{Materials and Methods}

$B$. thuringiensis type strains and isolates : Reference strains $B$. thuringiensis biovar israelensis (BGSC 4Q2) and $B$. thuringiensis serovar dakota strain 4R2 for parasporin 2 were kindly supplied by Dr. Zeigler (Bacillus Genetic Stock Center,
Colombus, $\mathrm{OH}, \mathrm{USA}$ ). Positive controls for parasporin 1, 5 and 6 genes were gifted from Dr. Rampersad (University of Texas-Pan American, Edinburg by, TX, USA). Native $B$. thuringiensis strains, used in this study, were originally isolated from boron containing soil samples of Balıkesir and Kütahya Province of Turkey.

Detection of cyt and parasporin genes : PCR was performed for detection of cyt and parasporin genes. Two pairs of primers synthesized from conserved regions of cyt 1 and cyt 2 genes were used for detection of cyt positive strains (Ibarra et al., 2003). Plasmid DNA was used as DNA template for PCR experiments. $P C R$ reactions were performed in a $50 \mu$ l volume containing 200 $\mu \mathrm{M}$ dNTP, $0.5 \mu \mathrm{M}$ of each primers, $1.5 \mathrm{mM} \mathrm{MgCl}_{2}$ and $2 \mathrm{U}$ of Taq DNA polymerase and $200 \mathrm{ng}$ DNA. Amplification was performed in a thermal cycler (PeqLab, Erlangen, Germany) using a 30 cycles of program. After an initial denaturation step at $95^{\circ} \mathrm{C}$ for 2 min, each cycle consists of a denaturation step at $95^{\circ} \mathrm{C}$ for $1 \mathrm{~min}$, a 1 min annealing step $\left(52^{\circ} \mathrm{C}\right.$ for cyt 1 and $50^{\circ} \mathrm{C}$ for cyt 2$)$ and an extention step at $72^{\circ} \mathrm{C}$ for $1 \mathrm{~min}$ and a final extention step at $72^{\circ} \mathrm{C}$ for 5 min was performed. The primers and amplification conditions for parasporin 1, 2, 3 and 4 genes as described by Lenina et al. (2014) and for parasporin 5 and 6 genes as described by Ammons et al. (2015) were used. After amplification, $10 \mu$ IPCR product was electrophoresed on a $1 \%$ agarose gel and visualized in a gel documentation system. All reagents for PCR were purchased from Thermo Scientific (Finland).

Preparation, solubilization and activation of parasporal proteins : Preparation of activated parasporal proteins was performed with minor modifications following the method of Brasseur et al. (2015). Briefly, B. thuringiensis isolates were grown at $30^{\circ} \mathrm{C}$ for $2-4$ days on nutrient agar until the cell lysis was completed. Harvested cells were washed two times with sterile distilled water. The spore-crystal pellet was solubilized in $500 \mu \mathrm{l}$ solubilisation buffer (56 mM Na $\mathrm{CO}_{3}, \mathrm{pH} 11,5$ and $11 \mathrm{mM}$ dithiothreitol) at $37^{\circ} \mathrm{C}$ for one hour. After that, insoluble material was removed by centrifugation at $6000 \times \mathrm{g}$ for $2 \mathrm{~min}$. Supernatant was transferred to a new centrifuge tube and $\mathrm{pH}$ was adjusted to 8 with $1 \mathrm{M}$ tris- $\mathrm{HCl}(\mathrm{pH} 4.98)$. Then, it was digested with proteinase $\mathrm{K}$ at a final concentration of $150 \mathrm{\mu g} \mathrm{ml}^{-1}$ for one hour at $37^{\circ} \mathrm{C}$. PMSF at $1 \mathrm{mM}$ final concentration was added to stop proteolytic reaction. SDS-PAGE analysis were performed to show parasporal protein profiles (Laemmli, 1970). Protein concentration was determined by Bradford method using bovine serum albumin as standard (Bradford, 1976).

Hemolytic activity assay : This assay was carried out according to a protocol described by Eren et al. (2008). Fresh human red blood cells (RBCs, $30 \mu \mathrm{l}$ ) were suspended in $10 \mathrm{ml}$ of TRIS saline. After washing three times by centrifugation for $5 \mathrm{~min}$ at $1500 \mathrm{rpm}$, it was resuspended in TRIS saline. Solubilized and activated parasporal protein samples $\left(10 \mu \mathrm{g} \mathrm{ml}^{-1}\right)$ were added to $80 \mu \mathrm{l}$ of the prepared RBC suspension to reach a final volume of $100 \mu \mathrm{l}$ in a 96 well plate. The plate was incubated at $37^{\circ} \mathrm{C}$ for 30 min under rotary agitation. After that, the plate was centrifuged (Microcentrifuge 200, Hettich) for $5 \mathrm{~min}$ at $3000 \mathrm{rpm}$ and the 
supernatants from the wells were transfered to a new plate. In order to determine the hemolysis, absorbance of released hemoglobin was measured at $405 \mathrm{~nm}$ using microplate reader (Multiscan FC, Thermo Scientific). A $10 \mu$ I Triton-X solution (20\%) was added to the above-prepared RBC suspension to achive $100 \%$ hemolysis as positive control. TRIS saline without parasporal protein served as negative control. Experiments were performed as triplicate.

Cells and culture conditions : Three human cancer cell lines; prostate cancer cell (PC-3), human cervix adenocarcinoma (HeLa) and lung cancer cell (A-549) were used in this study. Normal lung epithelial cells (BEAS-2B) served as control for certain experiments. All the cell lines were originally obtained from ATCC. Cells were maintained in RPMI 1640 medium containing 10\% fetal bovine serum, penicillin $\left(100 \mathrm{U} \mathrm{ml}^{-1}\right)$ and streptomycin $\left(100 \mu \mathrm{g} \mathrm{ml}^{-1}\right)$ in $5 \% \mathrm{CO}_{2}, 95 \%$ air in a humified incubator.

Cytotoxicity assay : Cytotoxic activity of parasporal protein preparations were determined by MTT assay (Applichem, USA). Each well of 96 well plates (Greiner, Germany) was seeded with $180 \mu$ l of cell suspension containing $2 \times 10^{4}$ cells and incubated for $24 \mathrm{hr}$ at $37^{\circ} \mathrm{C}$ in $5 \% \mathrm{CO}_{2}$ and $95 \%$ air in a humidified incubator. Solubilized and activated $B$. thuringiensis toxins in solubilization buffer were diluted in culture medium and added to the cell culture at a final concentration of $10 \mathrm{~g} \mathrm{~m} \mathrm{ml}^{-1}$. After incubating the cells for $24 \mathrm{hr}, 10 \mu \mathrm{l} \mathrm{MTT}$ solution $\left(5 \mathrm{mg} \mathrm{m}^{-1}\right)$ was added to each well and incubated for $4 \mathrm{hr}$ at $37^{\circ} \mathrm{C}$. The medium was then discarded and $100 \mu \mathrm{l}$ DMSO were added to each well in order to dissolve formazan blue crystals. Optical density was determined by reading the absorbance at $540 \mathrm{~nm}$ in a microplate reader (Thermo Scientific, Multiscan FC). Each experiment was carried out as triplicate. Cytotoxicity was determined by comparing the optical density of treated cells against the optical density of untreated cells.

Statistical analysis : The differences between applications were determined by one way analysis of variance (ANOVA) or KruskalWallis depending on variance was homogenous. Comparision of experimental groups, when using ANOVA, were determined by Dunnett and Tukey tests. Statistical significance level was accepted at ${ }^{*} p<0.05,{ }^{* *} p<0.01$ and ${ }^{* * *} p<0.001$. Data are presented as mean \pm SD of three replicates.

\section{Results and Discussion}

Cytocidal activity against human cancer cells was achieved by parasporal proteins from non-incesticidal and nonhemolytic $B$. thuringiensis strains by Okassov et al. (2015). Unlike Cry proteins, Cyt proteins exhibit a general cytolytic and hemolytic activity (Guerchicoff et al., 2001; Butko, 2003). Therefore, firstly fourteen native $B$. thuringiensis strains harboring cry 1 and/or cry 2 genes (Şahin et al., 2017) were screened for the presence of cyt genes using primers for cyt 1 and cyt 2 genes in order to eliminate cytoliytic and hemolytic $B$. thuringiensis strains. In total, five $B$. thuringiensis strains showed amplification with cyt gene primers. Bt-BB48 strain harbored only cyt 1 gene while Bt-KE-6364, Bt-KH 3 and Bt-BB99 strains harbored only cyt 2 gene and the strain $\mathrm{Bt}-\mathrm{KH} 58$ contained both cyt 1 and cyt 2 genes together (Fig. 2 A). However, 9 strains
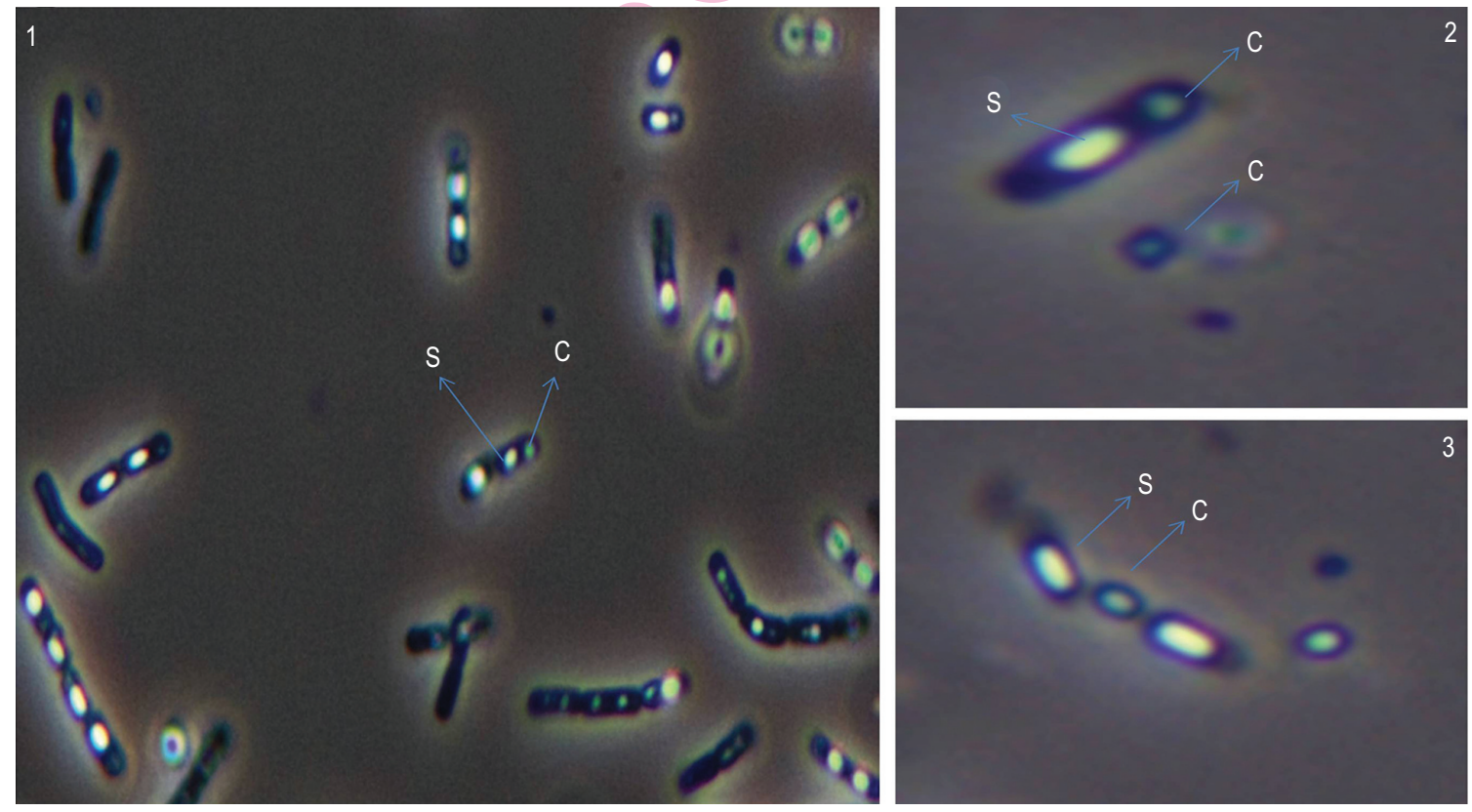

Fig. 1 : Phase contrast microscopy photographs of Bt strains: (1) Bt-KE63-64; (2) Bt-KH58 and (3) Bt-Ba14 isolates. S : spore; C : crystal. 


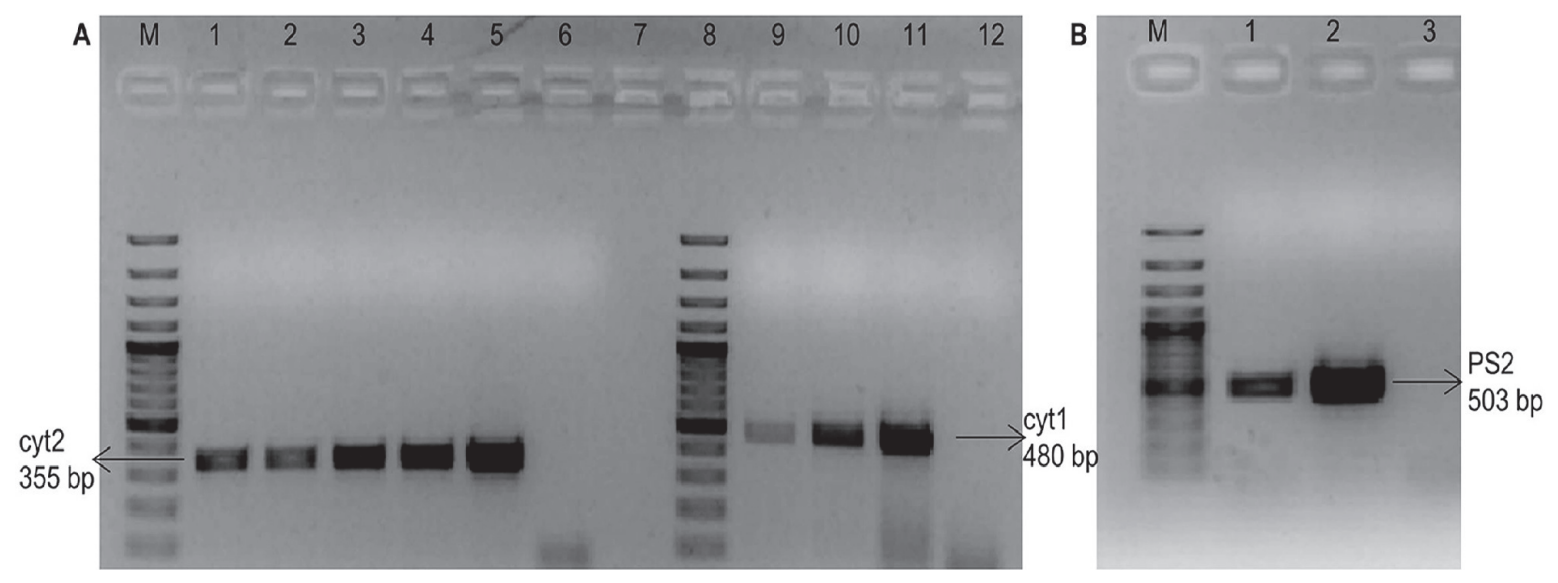

Fig. 2 : cyt and parasporin 2 gene profiles of Bt isolates: (A) Lanes 1-6 show cyt 2 profiles of 1:Bt-KE63-64;2: Bt-KH58; 3: Bt-KH3; 4: Bt-BB99; 5: Positive control (Bt israelensis); 6: Negative control. Lanes 8-12 show cyt 1 profiles of Bt strains. 8: Marker; 9: Bt-KH 58; 10: Bt-BB4; 11: Positive control (Bt israelensis); 12: Negative control. (B) Lanes 1-3 show parasporin 2 of 1: Bt-Ba14; 2: 4R2 reference strain; 3: Negative control.

showed no amplification for none of the cyt genes and therefore; the cyt gene negative strains were used for investgation of in vitro cytotoxic potential of parasporal proteins. Distrubition of cyt genes among $B$. thuringiensis strains change according to the environment. Gao et al. (2008) reported that in total of 143 B. thuringiensis isolates, only 9 isolates $(6 \%)$ harbored cyt genes. However, cyt gene content of $B$. thuringiensis strains in this study was $35 \%$. Parasporal proteins exhibiting cytocidal activity against leukemia T-cells and other human cancer cells are called parasporins. Based on amino acid identity, there are 6 main
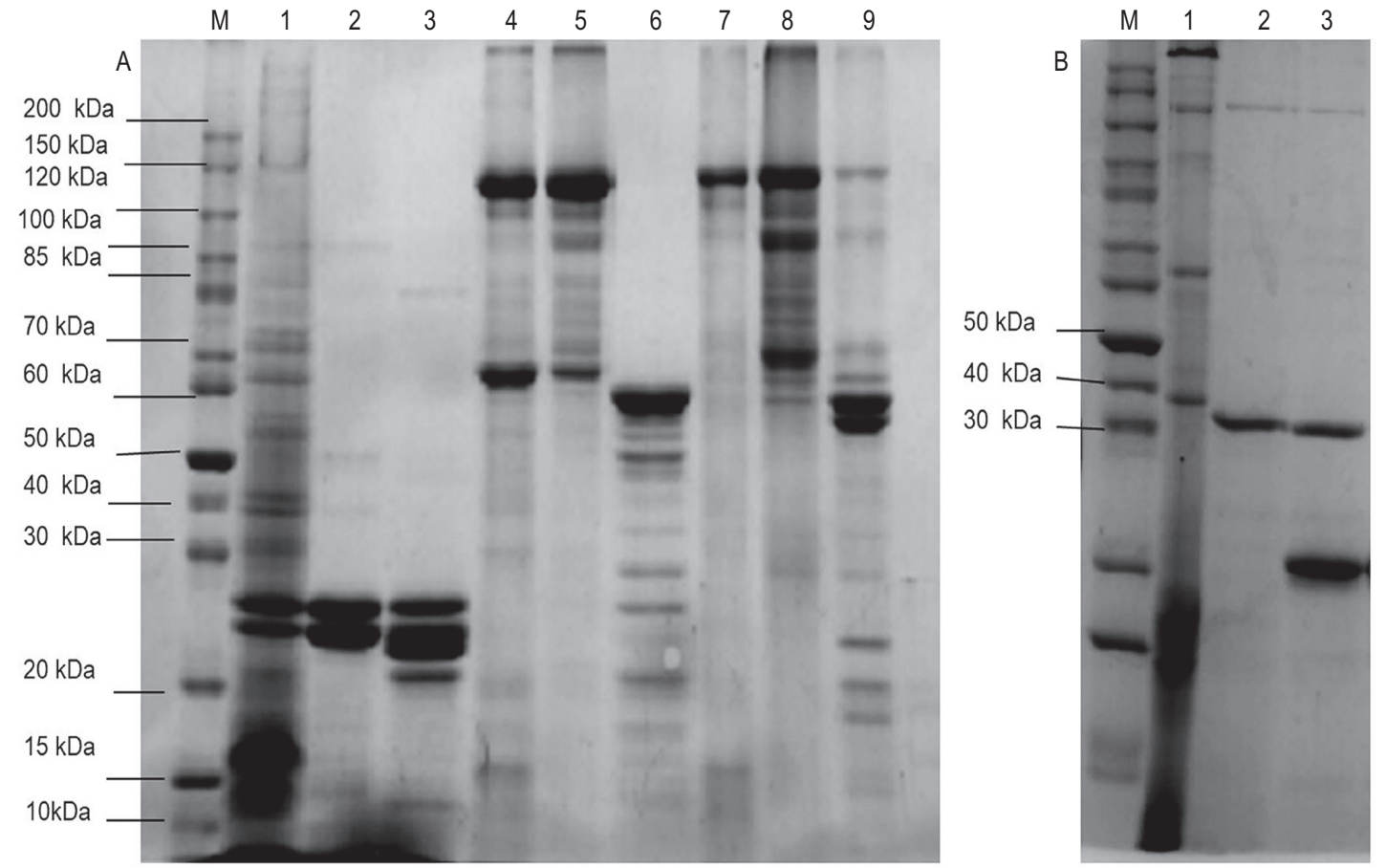

Fig. 3 : SDS-PAGE analysis. Protein profiles of Bt strains are given in following order: spore-crystal mixture, alkali solubilized and proteinase $\mathrm{K}$ treated parasporal proteins. (A) M: protein molecular weight marker, SM0661 (Fermentas); Lanes 1,2,3: Bt israelensis; Lanes 4,5,6: Bt-KH58; Lanes 7,8,9: BtKE-6364. (B) M: protein marker; Lanes 1,2,3: Bt-Ba14. 

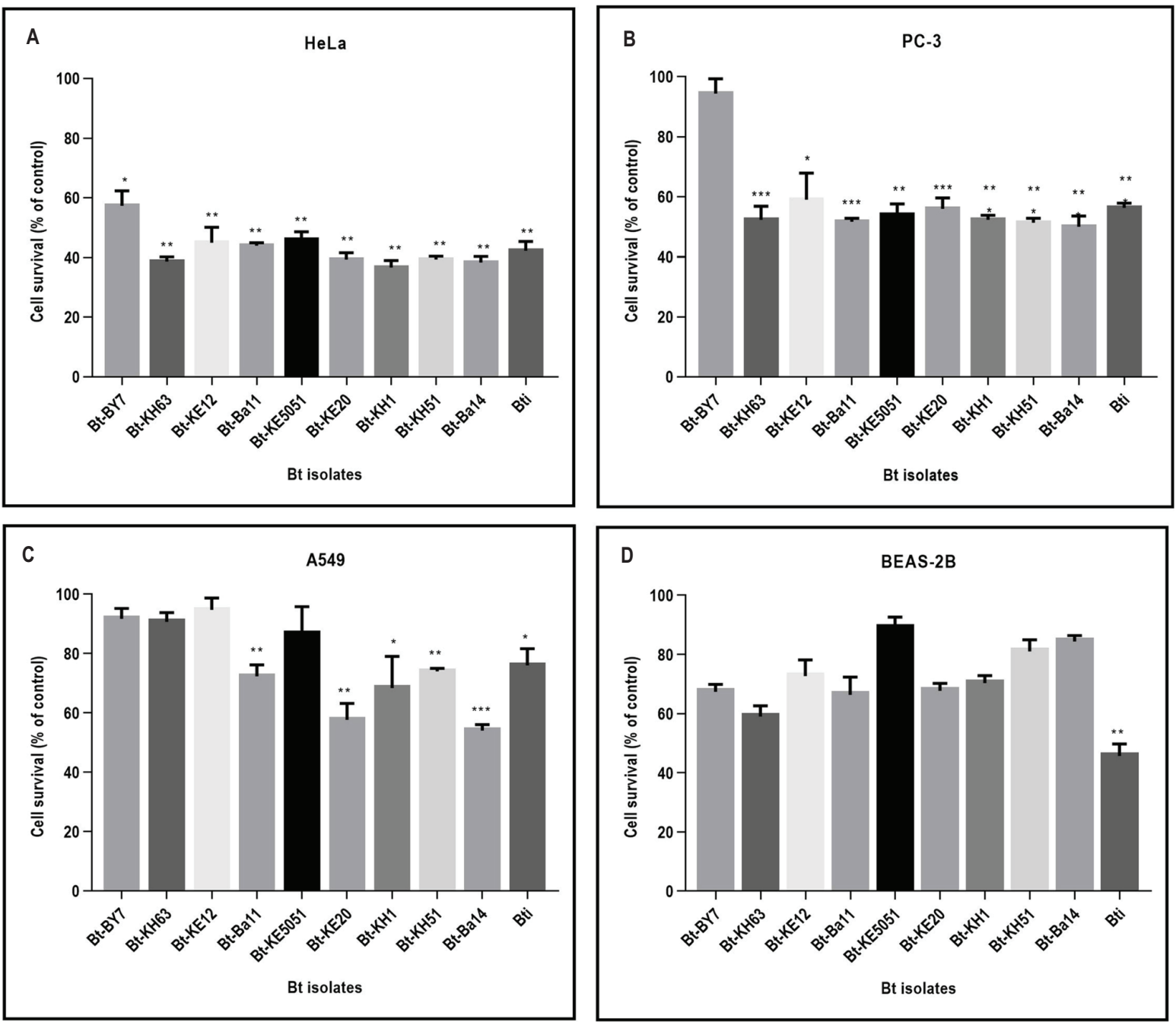

Fig. 4 : Cytotoxic effects of parasporal proteins from diferent Bt strains. The cells were plated onto 96 -well plates and treated with activated parasporal protein $\left(10 \mathrm{~g} \mathrm{~m} \mathrm{~m}^{-1}\right)$ for $24 \mathrm{hr}$. Cytotoxicity was determined based on MTT assay. Data are means of three replicates $\pm S D$. $: P<0.05 ; * *: P<0.01 ; * * *: P<0.001$

classes of parasporins encoded by different parasporin genes. Therefore, PCR analysis of each different parasporin genes (from 1 to 6 ) was carried out to see if these native strains contain any of the known parasporin genes (Fig. 2B). Our findings indicated that $\mathrm{Bt}-\mathrm{Ba} 14$ was the only strain harboring parasporin 2 and exhibiting PCR product at $503 \mathrm{bp}$, same as the band observed with parasporin 2 positive 4R2 reference strain (Brasseur et al., 2015). On the other hand, rest of the parasporin genes were not detected in $14 \mathrm{~B}$. thuringiensis strains. Low abundance of parasporin positive $B$. thuringiensis strains in our collection is consistent with the results of Mizuki et al. (1999). They showed that among 1744 $B$. thuringiensis strains, only $42 B$. thuringiensis strains exhibited in vitro cytotoxicity against human leukemic T-cells and these strains were cyt negative (non-cyt) and non-hemolytic. Similarly, a total of 9 non-cyt Bt strains was identified as non-hemolytic after performing hemolytic activity assay. The spore-crystal mixture was prepared from the sporulated $B$. thuringiensis cultures as described in methods section. Solubilization of parasporal proteins were carried out in different alkaline conditions ranging from $\mathrm{pH} 9$ to $\mathrm{pH} 12$ (data not shown). Because the optimum solubilization was observed at $\mathrm{pH} 11.5$, all solubilization studies were done under this alkaline condition. In addition, the amount of proteinase $\mathrm{K}$ for digestion of parasporin was optimized as well. Eventually, solubilized and activated parasporal proteins were prepared from nine $B$. thuringiensis strains.

SDS-PAGE analysis of representative three strains are shown in Fig. 3A. The alkali solubilized protein profiles of isolates revealed that the solubilization process works under the experimental conditions described and removes the unsoluble 

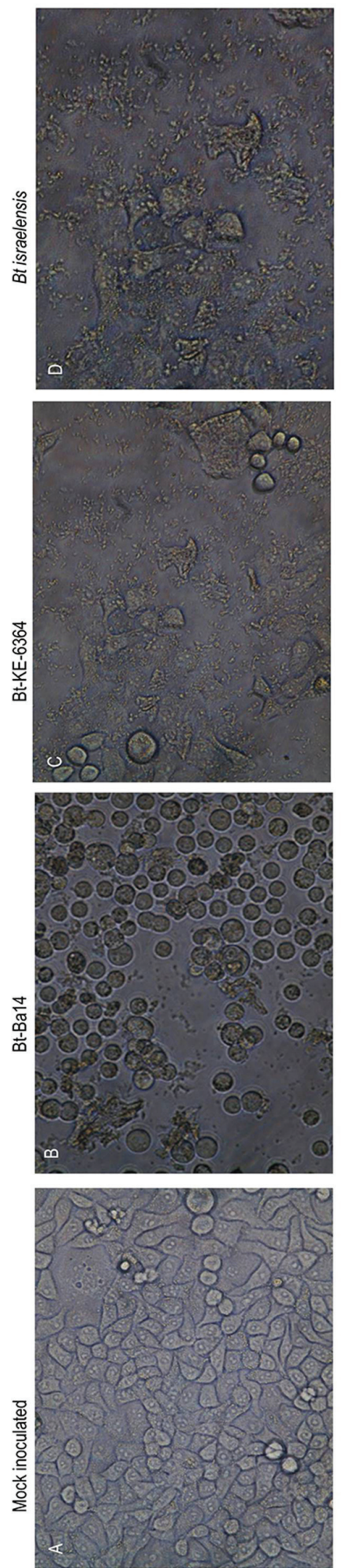

${ }^{\mathrm{e}}$
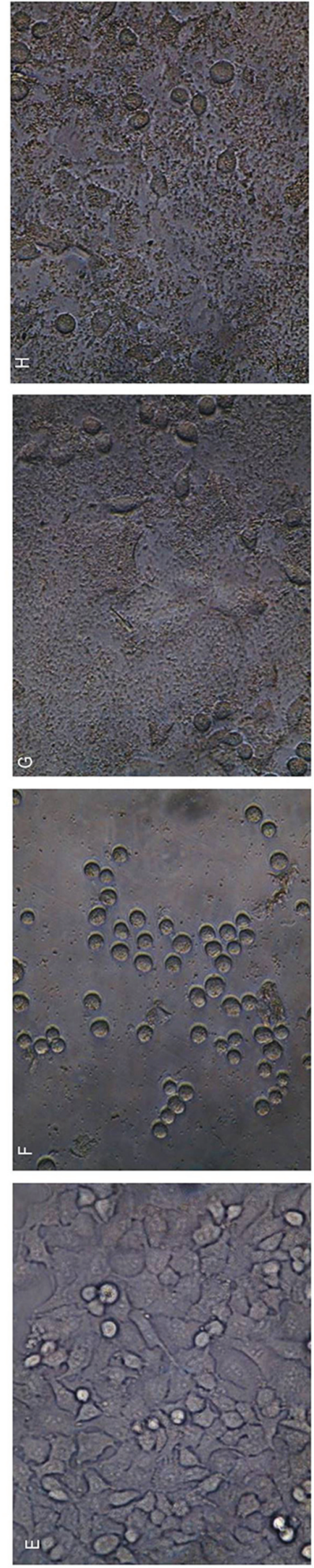

$6 \triangleright 9 \forall$
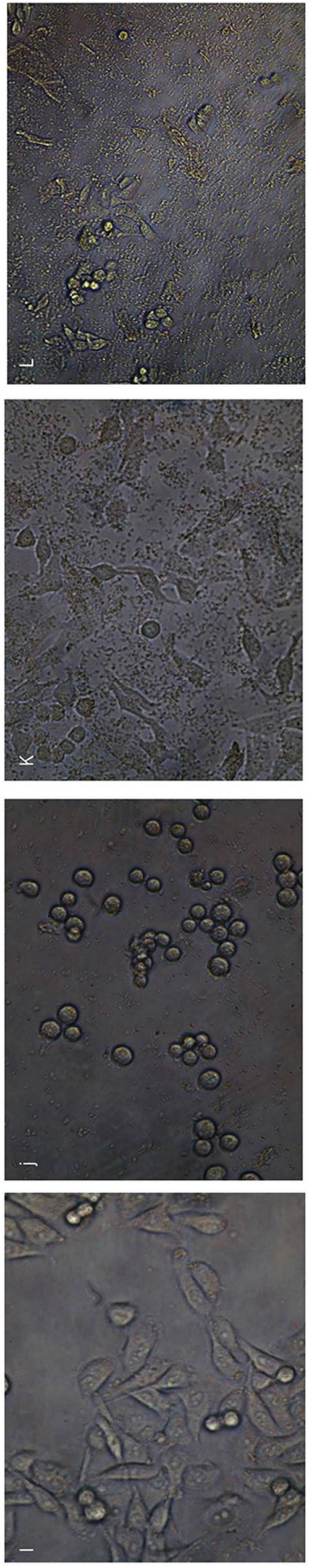

$\varepsilon-\supset$ d

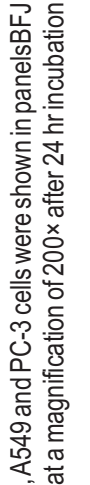

它

뚜유유

용

需

엉

응 흠

营.

든

$\sum$ 을 일

.

竞 $\frac{8}{8}$

芭.

范

幽

동 용

은 휴

혼

일.

흥.

흉 등

푼

要

离 $\frac{0}{10}$

음

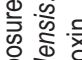

这娄

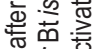

을 흔

언공요 잉

헝웡 웡

듀 흥

过

\&

ब이

든

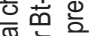

넘 흥

응 喜

응 仓

흔

$\sum_{i \infty}^{\infty}$

in

운

* Journal of Environmental Biology, November 2018 * 
proteins. Therefore, characteristic protein bands were fewer than spore crystal mixture of Bt cultures. Fig. 3 A shows the protein profile of isolates were different from Bt israelensis and from each other.

Moreover, SDS-PAGE analysis of parasporin 2 positive $\mathrm{Bt}-\mathrm{Ba} 14$ strain indicates unsolubilised protein band at $37 \mathrm{kDa}$ (Fig. 3B Lane1) as shown before (Brasseur et al., 2015). After solubilization and activation, Parasporin 2 exists as $30 \mathrm{kDa}$ protein (Wong et al., 2010). Similarly, Parasporin 2 was obtained at the same molecular weight (Fig. 3B, Lanes 2, 3).

Before cytotoxicity analysis, parasporal protein preparations from each of the $9 \mathrm{Bt}$ strains negative for cyt genes were tested for hemolysis and found that none of them exhibited hemolytic activity (data not shown). Even though only one strain $\mathrm{Bt}-\mathrm{Ba} 14$ was shown to have one of the known parasporin gene, cytotoxic effects of solubilized and activated parasporal proteins from other $8 \mathrm{Bt}$ strains were tested as well because they may contain unidentified cytotoxic protein. Hence, solubilized and activated parasporal proteins from $9 B$. thuringiensis strains were tested for cytotoxicity against HeLa, PC-3 and A549 cancer cell lines as well as a normal lung epithelial cell line BEAS-2B. Cytotoxic activity of Bt israelensis was used as control because of its indiscriminative cytolytic toxicity aganist a broad spectrum of cell lines due to its Cyt 1 and Cyt 2 proteins (Yamashita et al., 2000).

Cell viability rates and the statistical significance of MTT results are shown in Fig. 4. The cytotoxic activities of parasporal proteins were higher on HeLa cells than other cell lines. Parasporal proteins of Bt-KH63, Bt-KH1, Bt-KE20 and Bt-Ba14 strains were highly toxic to HeLa cells with the cell death rates of $61.6,63.4,61.4$ and 61.6 , respectively whereas they were less effective against normal cell line BEAS-2B (Fig. 4A and D). Especially, Bt-Ba14, Bt-KH51, Bt-KE5051 gave rise to less than $18 \%$ cytotoxicity against BEAS-2B cells indicating selectivity of these parasporal proteins on cancer cells.

The most cytotoxic parasporal proteins on PC-3 cells were obtained from Bt-Ba14,Bt-Ba11, Bt-KH1, Bt-KH51 and BtKH51 isolates that showed around 50\% cytotoxicity (Fig. 4B). On the other hand, the cytotoxic activity of $B$. thuringiensis strains against A549 cells was lower than other cell lines. Among the parasporal toxins tested, Bt-Ba 14 was most effective and selective toxin against A549 cells with the cell death rate of $48 \%$ because it caused $17 \%$ cytotoxicity against BEAS-2B cells (Fig. 4D). In short, most of the $B$. thuringiensis strains showed different range of cytotoxicity against the cancer cell lines and especially Bt-Ba14 exhibited a selective cytotoxicity against all 3 cancer cell lines but not against normal cell line BEAS-2B. In other words, cytotoxicity of $\mathrm{Bt}-\mathrm{Ba} 14$ against all cancer cells was higher than 2.8-fold compared to normal BEAS-2B cell.

Unlike Bt-Ba14, rest of the Bt strains exhibiting cytotoxic activity did not contain any known parasporin genes. The reason for this is that they may probably carry parasporal proteins different from currently identified parasporins. In fact, Nadarajah et al. (2008) reported no sequence similarity between parasporal protein from Bt-18 and parasporins; however, they showed that polypeptide from Bt-18 share similar properties with parasporin because it is non hemolytic but discriminately cytotoxic against leukemic cell lines. Therefore, further studies focusing on detalied characterization of parasporal proteins especially from $\mathrm{Bt}-\mathrm{Ba} 14$ may provide a new addition to the parasporin list. Up to date, more than 19 parasporins have been discovered and added to the list of parasporins by the committee (Okumura et al., 2010; Okassov, 2015).

When the morphological changes induced by parasporal proteins from cyt positive and cyt negative Bt strains were analysed by inverted microscopy, it was observed that cyt positive isolates such as Bt-KE6364 lead to drastic cell lysis (Fig. 5 C,G,K) as it was observed with Bt israelensis (Fig. $5 \mathrm{D}, \mathrm{H}, \mathrm{L}$ ). However, parasporal protein from parasporin 2 positive and cyt negative strain Bt-Ba 14 caused cell death with cell balloning (Fig. 5 B,F,J) which is characterized by parasporin proteins (Mizuki et al., 2000; Gao et al., 2008; Ekino et al., 2014). This result indicate that the $\mathrm{Bt}-\mathrm{Ba} 14$ strain is a potential candidate for full characterization and production of anti-cancer parasporin against cancer cells.

In conclusion, parasporal proteins from non-cyt and nonhemolytic Bt strains exhibited cytotoxicity against cancer cell lines at different levels. Because Bt-Ba14 strain displayed the most effective and selective cytotoxicity against cancer cell lines compared to a normal cell line, $\mathrm{Bt}-\mathrm{Ba} 14$ is a promising candidate for further characterization of mechanism of action on cancer cell death and development of anti-cancer agent.

\section{Acknowledgment}

This work was supported by Scientific Research Projects (BAP) of Mugla Sıtkı Kocman University in Turkey under project number $15 / 152$.

\section{References}

Ammons, D.R., J.D. Short, J. Bailey, G. Hinojosa, L. Tavarez, M. Salazar and J.N. Rampersad: Anti-cancer parasporin toxins are associated with different environments : Discovery of two novel Parasporin 5-like genes. Curr. Microbiol., 72, 184-189 (2015).

Bradford, M.M.: A rapid sensitive method for quantitation of microgram quantities of protein utilizing the principle of protein-dye binding. Anal. Biochem., 72, 248-254 (1976).

Brasseur, K., P. Auger, E. Asselin, S. Parent, J.C. Côté and M. Sirois: Parasporin-2 from a new Bacillus thuringiensis 4R2 strain Induces caspases activation and apoptosis in human cancer cells. PLoS One, 10, e0135106 (2015).

Butko, P.: Cytolytic toxin Cyt1 A and its mechanism of membrane damage: Data and hypotheses. Appl. Environ. Microbiol., 69, 2415-2422 (2003).

Crickmore, N., D.R. Zeigler, J. Feitelson, E. Schnepf, J. Van Rie, D. Lereclus, J. Baum and D.H. Dean: Revision of nomenclature for the Bacillus thuringiensis pesticidal crystal proteins. Microbiol. Mol. Biol. Rev., 62, 807-813 (1998). 
Ekino, K., S. Okumura, T. Ishikawa, S. Kitada, H. Saitoh, T. Akao, T. Oka, Y. Nomura, M. Ohba, T. Shin and E. Mizuki : Cloning and characterization of a unique cytotoxic protein parasporin-5 produced by Bacillus thuringiensis A1100 strain. Toxins, 6 , 18821895 (2014).

Eren, T., A. Som, J.R. Rennie, C.F. Nelson, Y. Urgina, K. Nusslein, E.B. Coughlin and G.N. Tew : Antibacterial and hemolytic activities of quaternary pyridinium functionalized polynorbornenesa. Macromol. Chem. Phys., 209, 516-524 (2008).

Gao, M., R. Li, S. Dai, Y. Wu and D. Yi : Diversity of Bacillus thuringiensis strains from soil in China and their pesticidal activities. Biol. Control, 44, 380-388 (2008).

Guerchicoff, A., A. Delécluse and C.P. Rubinstein : The Bacillus thuringiensis cyt genes for the hemolytic endotoxins constitude a gene family. Appl. Environ. Microbiol., 67, 1090-1096 (2001).

Höfte, H. and H.R. Whiteley : Insecticidal crystal proteins of Bacillus thuringiensis. Microbiol. Rev., 53, 242-255 (1989).

Ibarra, J., M.C. Rincón, S. Ordúz, D. Noriega, G. Benintende, R. Monnerat and A. Bravo : Diversity of Bacillus thuringiensis strains from Latin America with insecticidal activity against different mosquito species. Appl. Environ. Mıcrob., 69, 5269-5274 (2003).

Kim, H.S., S. Yamashita, T. Akao, H. Saitoh, K. Higuchi, Y.S. Park, E. Mizuki and M. Ohba : In vitro cytotoxicity of non-cyt inclusion proteins of a Bacillus thuringiensis isolate against human cells, including cancer cells. J. Appl. Microbiol., 89, 16-23 (2000).

Laemmli, U.K. : Cleavage of structural proteins during the assembly of the head of bacteriophage T4. Nature, 227, 680-685 (1970).

Lenina, N.K., A. Naveenkumar, A.E. Sozhavendan, N. Balakrishnan, V. Balasubramani and V. Udayasuriyan : Characterizatation of parasporin gene harbouring Indian isolates of Bacillus thuringiensis. 3 Biotech., 4, 545-551 (2014).

Mizuki, E., M. Ohba, T. Akao, S. Yamashita, H. Saitoh and Y.S. Park Unique avtivity associated with non-insecticidal Bacillus thuringiensis parasporal inclusions : In vitro cell-killing action on human cancer cells. J. Appl. Microbiol., 86, 477-486 (1999).

Mizuki, E., Y.S. Park, H. Saitoh, S. Yamashita, T. Akao, K. Higuchi and M. Ohba: Parasporin a human leukemic cell-recognizing parasporal protein of Bacillus thuringiensis. Clin. Diagn. Lab. Immunol., 7, 624-634 (2000).

Nadarajah, V.D., D. Ting, K.K. Chan, S.M. Mohamed, K. Kanakeswary and
H.L. Lee : Selective cytotoxic activity aganist leukemic cell lines from mosquitocidal Bacillus thuringiensis parasporal inclusions. Southeast Asian J. Trop. Med. Public Hlth., 39, 235-245 (2008).

Ohba, M., N. Wasano and E. Mizuki : Bacillus thuringiensis soil populations naturally occuring in the Ryuksus a subtropic region of Japan. Microbiol. Res., 155, 17-22 (2000).

Okassov,A.: Parasporins as a new anticancer agents : Areview. J. Buon., 20,5-16 (2015).

Okumura, S., M. Ohba, E. Mizuki, N. Crickmore, J.C. Cote, Y. Nagamatsu, S. Kitada, H. Sakai, K. Harata and T. Shin : Parasporin nomenclature http://parasporin.fitc.pref.fukuoka.jp / Accesed 14 May 2015 (2010).

Palma, L., D. Muñoz, C. Berry, J. Murillo and P. Caballero : Bacillus thuringiensis toxins : An overview of their biocidal activity. Toxins, 6,3296-3325 (2014).

Roh, J.Y., J.Y. Choi, M.S. Li, B.R. Jin and Y.H. Je : Bacillus thuringiensis as a specific, safe, and effective tool for insect pest control. J. Mol. Biol., 17, 547-559 (2007).

Salehi Jouzani, G.H., A. Seifinejad, A. Saeedizadeh, A. Nazarian, M. Yousefloo, S. Soheilivand, M. Mousivand, R. Jahangiri, M. Yazdani, R. Maali Amiri and S. Akbari : Molecular detection of nematicidal crystalliferous Bacillus thuringiensis strains of Iran and evaluation of their toxicity on free-living and plant-parasitic nematodes. Can. J. Microbiol., 54, 812-822 (2008).

Şahin, B., B. Çöl and H. Güneş : Bacillus thuringiensis isolation from environments of boron mines and effects of boric acid on bioactivity. GU J. Sci., 30, 223-234 (2017).

Schnepf, E., N. Crickmore, R.J. Van, D. Lereclus, J. Baum, J. Feitelson, D.R. Zeigler and D.H. Dean : Bacillus thuringiensis and its pesticidal crystal proteins. Microbiol. Mol. Biol. R., 62,775-806 (1998).

Soberon, M., J.A. Lopez-Diaz and A. Bravo: Cyt toxins produced by Bacillus thuringiensis : A protein fold conserved in several pathogenic microorganisms. Peptides, 41, 87-93 (2012).

Wong, R.S.Y., S.M. Mohamed, V.D. Nadarajah and I.A.T. Tengku : Characterisation of the binding properties of Bacillus thuringiensis 18 toxin on leukaemic cells. J. Exp. Clın. Canc. Res., 29, 86 (2010).

Yamashita, S., T. Akao, E. Mizuki, H. Saitoh, K. Higuchi, Y.S. Park, H.S. Kim and M. Ohba : Characterization of the anti-cancer-cell parasporal proteins of a Bacillus thuringiensis isolate. Can. J. Microbiol., 46, 913-919 (2000). 